\title{
PROBLEMATIKA YURIDIS PERATURAN PEMERINTAH NOMOR 21 TAHUN 2020 DALAM PERSPEKTIF ILMU PERUNDANG-UNDANGAN
}

\author{
Ahmad Gelora Mahardika \\ Institut Agama Islam Negeri Tulungagung | Jl. Major Sujadi Timur No.46 \\ Tulungagung | geloradika@gmail.com
}

\begin{abstract}
Covid-19 pandemic outbreak is a new phenomenon for Indonesian Government. Although Indonesia already has regulations, The 2018 Health Quarantine Act Number 6. However, the law requires government regulations to be implemented. Based on this, President issued The 2020 Government Regulation Number 2 I , as a legal basis for the enactment of Large-Scale Social Restrictions. However, formally and materially, many problems on The 2020 Government Regulation Number 21. In addition, the material regulated in Government Regulations does not answer the questions contained on The 2018 Health Quarantine Act Number 6. Therefore, this article wants to answer questions related to how the juridical analysis of The 2020 Government Regulation Number 2I in the perspective of legislation. The method of research in this article is normative juridical by analyzing a number of laws and regulations. The conclusion in this article is that The 2020 Government Regulation Number 21 does not meet the minimum requirements as a implementing regulation, it is necessary to make a new government regulation to replace it.
\end{abstract}

Key Words: pandemic; regulation; law

Abstrak: Wabah pandemi Covid-19 merupakan fenomena baru bagi Pemerintah Indonesia. Meskipun pada hakikatnya, Indonesia telah mempunyai regulasi yang mengatur hal tersebut yaitu Undang-Undang Nomor 6 Tahun 2018 tentang Kekarantinaan Kesehatan. Akan tetapi, Undang-Undang tersebut memerlukan peraturan pemerintah untuk dapat dilaksanakan. Berdasarkan hal tersebutlah, Presiden kemudian menerbitkan Peraturan Pemerintah Nomor 21 Tahun 2020 sebagai landasan hukum diberlakukannya Pembatasan Sosial Berskala Besar. 
Namun, secara formil maupun materiil, Peraturan Pemerintah Nomor 21 Tahun 2020 menyimpan banyak persoalan. Selain itu, materi yang diatur dalam Peraturan Pemerintah sama sekali belum menjawab pertanaan yang terdapat dalam Undang-Undang Nomor 6 Tahun 2018. Oleh karena itulah, artikel ini hendak menjawab pertanyaan terkait bagaimanakah analisis yuridis Peraturan Pemerintah Nomor 21 Tahun 2020 dalam perspektif ilmu perundang-undangan. Metode penelitian dalam artikel ini adalah yuridis normatif yaitu dengan menganalisis sejumlah peraturan perundang-undangan. Kesimpulan dalam artikel ini adalah Peraturan Pemerintah Nomor 21 Tahun 2020 belum memenuhi syarat minimal sebagai suatu peraturan pelaksana yang layak, oleh karena itulah perlu di buat peraturan pemerintah baru untuk menggantikannya.

Kata Kunci : pandemi; peraturan; undang-undang

\section{Pendahuluan}

Wabah pandemi Covid-19 yang terjadi di dunia telah memaksa setiap negara untuk mengambil tindakan tertentu sebagai upaya pencegahan menyebarnya virus tersebut. Di Indonesia, pada hakikatnya sudah terdapat regulasi yang mengatur terkait penanganan wabah pandemi sebagaimana Covid-19 yaitu UndangUndang Nomor 6 Tahun 2018 tentang Kekarantinaan Kesehatan. Dalam ketentuan yang terdapat pada regulasi tersebut, ada beberapa tindakan yang dapat dilakukan oleh Pemerintah untuk mengatasi merebaknya wabah pandemi antara lain Karantina Rumah, Karantina Wilayah, Karantina Rumah Sakit, atau Pembatasan Sosial Berskala Besar. Akan tetapi, sebagaimana Undang-Undang pada umumnya, Undang-Undang Nomor 6 Tahun 2018 tentang Kekarantinaan Kesehatan juga membutuhkan peraturan pelaksana untuk dapat diterapkan di masyarakat, ketentuan itu tercantum pada pasal 60 yang menyatakan bahwa pengaturan lebih lanjut mengenai kriteria dan pelaksanaan Karantina Rumah, Karantina Wilayah, Karantina Rumah Sakit, dan Pembatasan Sosial Berskala Besar diatur dengan Peraturan Pemerintah.

Tindakan Pemerintah untuk menerbitkan Peraturan Pemerintah Nomor 21 Tahun 2020 tentang Pembatasan Sosial 
Berskala Besar Dalam Rangka Percepatan Penanganan Corona Virus Disease 2019 (Covid-19) pada hakikatnya merupakan amanat dari Undang-Undang Nomor 6 Tahun 2018, dalam artian Peraturan Pemerintah tersebut selayaknya merupakan penjabaran teknis dari sejumlah norma yang mengatur terkait terkait opsi-opsi yang bisa diambil Pemerintah untuk mengatasi wabah pandemi. Akan tetapi Pemerintah memilih untuk menggunakan PSBB sebagai satusatunya tindakan mitigasi untuk mengatasi wabah. Oleh karena itulah, Peraturan Pelaksana yang diterbitkan Pemerintah tersebut hanya mengatur secara spesifik tentang Pembatasan Sosial Berskala Besar (PSBB) bukan tentang karantina rumah, karantina rumah sakit maupun karantina wilayah.

Mengacu pada doktrin yang digagas Adolf Julius Merkl yaitu das doppelte rechtsanilitz, yang mana norma hukum memiliki dua wajah, yaitu norma hukum itu keatas ia bersumber dan berdasar pada norma yang ada diatasnya; dan Norma hukum ke bawah, ia juga menjadi dasar dan menjadi sumber bagi norma yang dibawahnya. ${ }^{1}$ Dalam konteks hierarki peraturan perundangundangan berdasarkan Pasal 7 ayat (1) Undang-Undang Nomor 12 Tahun 2011, maka pembentukan Peraturan Pemerintah Nomor 21 Tahun 2020 selayaknya merujuk pada Undang-Undang Nomor 6 Tahun 2018. Hal tersebut bisa dilihat pada diktum mengingat pada poin ke-4 pada Peraturan Pemerintah tersebut yang merujuk pada Undang-Undang Nomor 6 tahun 2018. Oleh karena itulah, Peraturan Pemerintah tersebut pada hakikatnya memang dihadirkan untuk menerjemahkan aturan teknis yang tercantum pada Undang-Undang Nomor 6 Tahun 2018 khususnya Pasal 59 yang mengatur terkait PSBB.

Akan tetapi, dalam prakteknya, Peraturan Pemerintah Nomor 21 Tahun 2020 tidak banyak memberikan solusi terhadap problematika tafsir yang tercantum dalam Pasal 59 UndangUndang Nomor 6 Tahun 2018. Hal itu bisa terlihat apabila mengamati batang tubuh Peraturan Pemerintah tersebut yang

I Maria Farida Indrarti, Ilmu Perundang-Undangan (Yogyakarta: Kanisius, 1998), 25. 
hanya terdiri atas 7 (tujuh) pasal, dengan mayoritas pasal merupakan reduplikasi dari Undang-Undang Nomor 6 Tahun 2018. Sehingga Peraturan Pemerintah yang selayaknya menjadi solusi terhadap masih abstraknya ketentuan yang terdapat dalam Undang-Undang Nomor 6 Tahun 2018 justru kemudian memunculkan problematika baru. Kondisi itulah yang kemudian membuat pelaksanaan Pembatasan Sosial Berskala Besar (PSBB) di sejumlah daerah tidak dapat berjalan dengan optimal. Lantas bagaimanakah Peraturan Pemerintah yang selayaknya diterbitkan oleh Pemerintah sebagai peraturan pelaksana pada Pasal 59 Undang-Undang Nomor 6 Tahun 2018 tentang Kekarantinaan Kesehatan?

Sebagai sebuah peraturan pelaksana yang diterbitkan ditengah wabah pandemi, penulis hendak mengkaji peraturan pemerintah tersebut baik dari aspek formil maupun materiilnya. Hal tersebut menjadi urgen untuk dikaji dikarenakan sebagai negara hukum rechstaat selayaknya segala tindakan Pemerintah harus didasarkan pada peraturan perundang-undangan.

\section{Aspek Formil PP Nomor 21 Tahun 2020}

Salah satu prinsip hukum yang dibangun di Indonesia pasca reformasi adalah memastikan segala produk hukum yang dikeluarkan mempunyai konsistensi antara norma formil dan norma materiil atau antara bentuk dan substansi. Hal itu disebabkan, dalam konteks negara hukum rechstaat terdapat tiga macam bentuk keputusan yang mengikat secara hukum bagi subjek-subjek hukum, yakni: ${ }^{2}$

1. Pengaturan menghasilkan peraturan (regels). Hasil kegiatan pengaturan itu disebut dengan istilah "peraturan".

2. Penetapan menghasilkan ketetapan atau keputusan (beschikkings). Hasilnya disebut "Keputusan" atau "Ketetapan".

3. Penghakiman atau pengadilan menghasilkan putusan atau vonnis

${ }^{2}$ Jimy Asshiddiqie, Perihal Undang-Undang (Jakarta: Konstitusi Press, 2006), 15. 
Setiap produk hukum mempunyai karakteristik masingmasing. Produk hukum ketetapan (beschikking) mempunyai sejumlah karakteristik sebagaimana yang tercantum pada UndangUndang Nomor 5 Tahun 1986 tentang Peradilan Tata Usaha Negara dan Undang-Undang Nomor 30 Tahun 2014 tentang Administrasi Pemerintahan bahwa keputusan/ketetapan (beschikking) mempunyai sejumlah karakteristik yaitu kongkret, individual dan final.

Selain produk hukum keputusan/ketetapan, terdapat produk hukum lain yaitu peraturan (regelling). Produk hukum peraturan (regelling) mempunyai batasan untuk membedakan dengan beschikking, yaitu suatu keputusan dapat dikategorikan sebagai peraturan yang bersifat mengatur bilamana pertama, kepentingan publik, kedua menyangkut hubungan hukum antara atau hubungan antara hak dan kewajiban diantara sesama warga negara, dan antara warga negara dengan negara, serta antara warga negara dengan pemerintah. ${ }^{3}$

Manakala melihat karakteristik Peraturan Pemerintah Nomor 21 Tahun 2020 tentang Pembatasan Sosial Berskala Besar Dalam Rangka Percepatan Penanganan Corona Virus Disease 2019 (Covid-19) dapatlah disimpulkan bahwa produk hukum tersebut termasuk dalam ranah peraturan (regelling) karena mengatur terkait hubungan hukum atau hak dan kewajiban antara warga negara dengan negara serta warga negara dengan pemerintah.

Menurut Ahmad Ahsin Thohari, setiap proses pembentukan peraturan yang baik selayaknya harus memperhitungkan aspek adaptif, futuristis, daya tahan (durability), dan umur panjang (longevity). ${ }^{4}$ Untuk melihat apakah Peraturan Pemerintah Nomor 21 Tahun 2020 tentang Pembatasan Sosial Berskala Besar Dalam Rangka Percepatan Penanganan Corona Virus Disease 2019 (Covid-19) dapat dikategorikan sebagai peraturan perundang-undangan yang baik ataukah tidak, maka

\footnotetext{
3 Zainal Arifin Houssein, "Pembentukan Hukum Dalam Perspektif Pembaruan Hukum," Rechtsvinding, Vol. I, No. 3 (2012), 257-275.

${ }^{4}$ Ahmad Ahsin Thohari, "Pendek Umur Peraturan," Kompas, July I 5, 2015.
} 
keempat variabel tersebut dapat digunakan untuk melakukan analisis.

1. Adaptif : Peraturan Pemerintah Nomor 21 Tahun 2020 mampu seketika diterapkan di masyarakat. Hal tersebut disebabkan peristiwa wabah pandemi sudah terjadi di Indonesia dan Pemerintah membutuhkan dasar hukum untuk mengatasi persoalan tersebut. Oleh karena itulah dalam konsep adaptif, Peraturan Pemerintah Nomor 21 Tahun 2020 telah memenuhi syarat sebagai peraturan perundang-undangan yang baik.

2. Futuristis : terkait futuristis atau antisipatif, Peraturan Pemerintah Nomor 21 Tahun 2020 terlihat tidak mengantisipasi kebutuhan akan kepastian hukum manakala terjadi wabah pandemi serupa kedepannya. Hal tersebut mengacu kepada judul Peraturan Pemerintah tersebut yaitu tentang Pembatasan Sosial Berskala Besar Dalam Rangka Percepatan Penanganan Corona Virus Disease 2019 (Covid-19). Judul tersebut secara langsung membatasi lingkup peraturan pemerintah tersebut hanya pada wabah pandemi Covid-19, jadi manakala terjadi wabah pandemi serupa namun dengan virus yang berbeda, maka Peraturan Pemerintah Nomor 21 Tahun 2020 tidak dapat digunakan.

3. Durability : mengacu pada judul Peraturan Pemerintahnya yang mana pembentukannya hanya difungsikan untuk mengatasi wabah pandemi Covid-19, maka bilamana wabah pandemi Covid-19 berakhir, Peraturan Pemerintah Nomor 21 Tahun 2020 tidak dapat digunakan lagi. Jangka waktunya dibatasi oleh berlangsungnya wabah pandemi Covid-19.

4. Longevity : sejalan dengan masa berlakunya (durability) yang dibatasi oleh berlangsungnya wabah pandemi Covid-19, maka secara otomatis lama berlakunya Peraturan Pemerintah Nomor 21 Tahun 2020 sangat bergantung dengan adanya wabah.

Berdasarkan hal tersebut diatas, terkait apakah Peraturan Pemerintah Nomor 21 Tahun 2020 telah memenuhi syarat sebagai 
Peraturan Perundang-undangan yang baik dapat dilihat pada tabel berikut:

Tabel 1

Peraturan Pemerintah Nomor 21 Tahun 2020 dalam Aspek Formil

\begin{tabular}{|l|l|l|}
\hline Aspek & Memenuhi & Tidak Memenuhi \\
\hline Adaptif & $\sqrt{ }$ & - \\
\hline Futuristis & - & $\sqrt{ }$ \\
\hline Durability & - & $\sqrt{ }$ \\
\hline Longevity & - & $\sqrt{ }$ \\
\hline
\end{tabular}

Berdasarkan variabel-variabel diatas, Peraturan Pemerintah Nomor 21 Tahun 2020 tentang Pembatasan Sosial Berskala Besar Dalam Rangka Percepatan Penanganan Corona Virus Disease 2019 (Covid-19) belum memenuhi kualifikasi sebagai Peraturan Perundang-undangan yang baik dari aspek pembentukannya (formil).

\section{Aspek Materiil PP Nomor 21 Tahun 2020}

Aspek materiil Peraturan Pemerintah Nomor 21 Tahun 2020 bisa dilihat berdasarkan materi muatan ayat, pasal, dan/atau bagian dari peraturan perundang-undangan tersebut. ${ }^{5}$

Apabila menilik Peraturan Pemerintah Nomor 21 Tahun 2020 yang berfungsi sebagai peraturan pelaksana dari UndangUndang Nomor 6 Tahun 2018, maka pijakan untuk mengetahui apakah materi muatan tersebut telah sesuai dengan yang diharapkan adalah dengan melakukan analisis terhadap ketentuan yang terdapat dalam Undang-Undang Nomor 6 Tahun 2018.

Materi muatan Peraturan Pemerintah Nomor 21 Tahun 2020 tentang Pembatasan Sosial Berskala Besar Dalam Rangka

5 Effendi Maftuh and Tri Cahya Indera Permana, "Usulan Rumusan Hukum Acara ( Ius Constituendum ) Pengujian Peraturan Perundang-Undangan Di Bawah Undang- Undang Oleh Mahkamah Agung," Media Hukum, Vol.2, No. I (2018), 31-39. 
Percepatan Penanganan Corona Virus Disease 2019 (Covid-19) hanya terdiri dari 7 (tujuh) pasal:

\section{Pasal 1}

Dalam Peraturan Pemerintah ini, yang dimaksud dengan Pembatasan Sosial Berskala Besar adalah pembatasan kegiatan tertentu penduduk dalam suatu wilayah yang diduga terinfeksi Corona Virus Disease 2019 (COVID-19) sedemikian rupa untuk mencegah kemungkinan penyebaran Corona Virus Disease 2019 (Covid-19).

Pasal 1 dalam Peraturan Pemerintah tersebut pada dasarnya hanyalah menyalin dari Pasal 1 ayat (11) Undang-Undang Nomor 6 Tahun 2018 dengan penambahan kata "Corona Virus Disease":

\section{Pasal 11}

Pembatasan Sosial Berskala Besar adalah pembatasan kegiatan tertentu penduduk dalam suatu wilayah yang diduga terinfeksi penyakit dan/atau terkontaminasi sedemikian rupa untuk mencegah kemungkinan penyebaran penyakit atau kontaminasi.

Sehingga dapat disimpulkan dalam Pasal 1 Peraturan Pemerintah Nomor 21 Tahun 2020 tidak ada unsur kebaruan sama sekali, karena hanya menambahkan satu kata yang mana justru membatasi jangkauan materi muatan dalam Peraturan Pemerintah tersebut. Sementara itu pada Pasal 2 terdiri dari 2 (dua) ayat:

\section{Pasal 2}

(1) Dengan persetujuan menteri yang menyelenggarakan urusan pemerintahan di bidang kesehatan, Pemerintah Daerah dapat melakukan Pembatasan Sosial Berskala Besar atau pembatasan terhadap pergerakan orang dan barang untuk satu provinsi atau kabupaten/ kota tertentu.

(2) Pembatasan Sosial Berskala Besar sebagaimana dimaksud pada ayat (1) harus didasarkan pada pertimbangan epidemiologis, 
besarnya ancaman, efektifitas, dukungan sumber daya, teknis operasional, pertimbangan politik, ekonomi, sosial, budaya, pertahanan dan keamanan.

Sebagaimana yang tercantum pada Pasal 1, Pasal 2 pun pada hakikatnya hanya ada satu ayat yang terdapat unsur kebaruan yaitu pada ayat (1), sementara itu pada ayat (2) hal tersebut sudah diatur pada Pasal 49 ayat (2) Undang-Undang Nomor 6 Tahun 2018, hanya saja beberapa frase ditiadakan untuk menyesuaikan dengan tema Peraturan Pemerintah tersebut.

Sementara itu pada Pasal 3 Peraturan Pemerintah Nomor 21 Tahun 2020 terdapat norma baru yang tidak terdapat pada UndangUndang Nomor 6 Tahun 2018 yaitu Pembatasan Sosial Berskala Besar harus memenuhi kriteria antara lain jumlah kasus dan atau jumlah kematian akibat penyakit meningkat dan menyebar secara signifikan dan cepat ke beberapa wilayah dan terdapat kaitan epidemiologis dengan kejadian serupa di wilayah atau negara lain. Ketentuan tersebut pada dasarnya merupakan turunan dari Pasal 60 Undang-Undang Nomor 6 Tahun 2018 yang mengatur terkait kriteria pelaksanaan pembatasan sosial berskala besar. Oleh karena itulah, menurut penulis pasal 3 Peraturan Pemerintah Nomor 21 Tahun 2020 merupakan inti (core) dari Peraturan Pemerintah ini.

Sementara itu Pasal 4 Peraturan Pemerintah Nomor 21 Tahun 2020 yang mengatur terkait tindakan pembatasan mempunyai kemiripan dengan 59 ayat (3) Undang-Undang Nomor 6 Tahun 2018.

Apabila dibandingkan antara dua ketentuan tersebut diatas dapatlah dibuat tabel sederhana sebagai berikut:

Tabel 2

Perbandingan Pasal 59 Undang-Undang Nomor 6 Tahun 2018 dan Pasal 4 Peraturan Pemerintah Nomor 21 Tahun 2020

\begin{tabular}{|l|l|}
\hline UU No. 6 Tahun 2018 & PP No. 21 Tahun 2020 \\
\hline $\begin{array}{l}\text { Peliburan sekolah dan } \\
\text { tempat kerja }\end{array}$ & $\begin{array}{l}\text { Peliburan sekolah dan tempat } \\
\text { kerja }\end{array}$ \\
\hline & $\begin{array}{l}\text { Harus mempertimbangkan } \\
\text { kebutuhan pendidikan }\end{array}$ \\
\hline
\end{tabular}




\begin{tabular}{|l|l|}
\hline & $\begin{array}{l}\text { Memperhatikan Produktivitas } \\
\text { kerja }\end{array}$ \\
\hline $\begin{array}{l}\text { Pembatasan kegiatan } \\
\text { keagamaan }\end{array}$ & Pembatasan kegiatan keagamaan \\
\hline & $\begin{array}{l}\text { Mempertimbangkan ibadah } \\
\text { penduduk }\end{array}$ \\
\hline $\begin{array}{l}\text { Pembatasan kegiatan di } \\
\text { tempat atau fasilitas umum }\end{array}$ & $\begin{array}{l}\text { Pembatasan kegiatan di tempat } \\
\text { atau fasilitas umum }\end{array}$ \\
\hline & $\begin{array}{l}\text { Harus memperhatikan } \\
\text { kebutuhan dasar penduduk }\end{array}$ \\
\hline
\end{tabular}

Sementara itu pada Pasal 5 Peraturan Pemerintah Nomor 21 Tahun 2020 terdapat kewenangan delegatif yang diberikan kepada Menteri Kesehatan, yang mana Pasal tersebut bukan merupakan pasal yang benar-benar baru, karena dalam Pasal 49 ayat (3) Undang-Undang Nomor 6 Tahun 2018 telah disebutkan hal yang sama.

Terkait dengan koordinasi dengan pihak terkait, hal tersebut juga sudah diatur pada Pasal 59 ayat (4) Undang-Undang Nomor 6 Tahun 2018. Sementara itu Pasal 6 Peraturan Pemerintah Nomor 21 Tahun 2020 merupakan tata cara penentuan wilayah yang dapat ditetapkan sebagai daerah Pembatasan Sosial Berskala Besar (PSBB) yang mana pengusulannya dilakukan oleh Ketua Pelaksana Gugus Tugas Percepatan Penanganan Corona Virus Disease 2019 dan penetapannya dilakukan oleh Menteri Kesehatan. Sedangkan pada Pasal 7 Peraturan Pemerintah tersebut merupakan ketentuan penutup.

Dalam Peraturan Pemerintah Nomor 21 Tahun 2020, hanya terdapat dua pasal yang betul-betul terdapat unsur kebaruan, yaitu: 1. Pasal 4 (empat), terkait pertimbangan peliburan tempat kerja, sekolah, pembatasan kegiatan keagamaan, dan fasilitas publik harus tetap mempertimbangkan kebutuhan pendidikan, produktivitas kerja, dan ibadah serta kebutuhan dasar penduduk. 
2. Pasal 6 (enam) terkait prosedur suatu daerah bilamana hendak menerapkan Pembatasan Sosial Berskala Besar (PSBB).

Akan tetapi menjadi pertanyaan adalah apakah kedua norma baru tersebut dalam Peraturan Pemerintah Noor 21 Tahun 2020 sudah memenuhi harapan pembuat undang-undang dalam upaya melakukan mitigasi penyebaran wabah melalui Pembatasan Sosial Berskala Besar (PSBB)?.

\section{Peraturan Pemerintah Sebagai Peraturan Pelaksana}

Salah satu hal yang kemudian harus ditekankan adalah bahwa posisi Peraturan Pemerintah Nomor 21 Tahun 2020 merupakan amanat dari Pasal 60 Undang-Undang Nomor 6 Tahun 2018 tentang Kekarantinaan Kesehatan yang menghendaki agar ketentuan lebih lanjut mengenai kriteria dan pelaksanaan Pembatasan Sosial Berskala Besar diatur dengan Peraturan Pemerintah.

Apabila melihat Undang-Undang Nomor 6 Tahun 2018, penyebutan frase "Pembatasan Sosial Berskala Besar" dilakukan sebanyak 10 (sepuluh) kali dalam batang tubuh (diluar judul Bab), yaitu:

\section{Tabel 3}

Penyebutan Frase Pembatasan Sosial Berskala Besar dalam Undang-Undang Nomor 6 Tahun 2018

\begin{tabular}{|l|l|}
\hline \multicolumn{1}{|c|}{ Pasal } & \multicolumn{1}{|c|}{ Terkait } \\
\hline Pasal 1 ayat (11) & $\begin{array}{l}\text { ketentuan umum yang menyebutkan definisi } \\
\text { Pembatasan Sosial Berkala Besar }\end{array}$ \\
\hline $\begin{array}{l}\text { Pasal 15 ayat (2) } \\
\text { huruf b }\end{array}$ & $\begin{array}{l}\text { tindakan-tindakan karantina kesehatan yang } \\
\text { bisa dilakukan oleh Pemerintah. }\end{array}$ \\
\hline Pasal 49 ayat (1) & $\begin{array}{l}\text { dengan mitigasi faktor risiko PSBB yang } \\
\text { kewenangannya diserahkan pada Pejabat } \\
\text { Karantina Kesehatan }\end{array}$ \\
\hline Pasal 49 ayat (2) & terkait pertimbangan dilakukannya PSBB \\
\hline Pasal 49 ayat (3) & penetapan PSBB yang dilakukan oleh Menteri \\
\hline Pasal 59 ayat (1) & $\begin{array}{l}\text { menyatakan bahwa PSBB merupakan bagian } \\
\text { dari kedaruratan kesehatan masyarakat }\end{array}$ \\
\hline
\end{tabular}




\begin{tabular}{|l|l|}
\hline Pasal 59 ayat (2) & menyatakan tujuan diadakannya PSBB \\
\hline Pasal 59 ayat (3) & $\begin{array}{l}\text { hal minimal yang dilakukan dalam PSBB, } \\
\text { yaitu peliburan tempat sekolah dan kerja, } \\
\text { pembatasan kegiatan keagamaan, dan } \\
\text { pembatasan kegiatan ditempat umum }\end{array}$ \\
\hline Pasal 59 ayat (4) & $\begin{array}{l}\text { koordinasi dan kerjasama dengan instansi } \\
\text { terkait }\end{array}$ \\
\hline Pasal 60 & $\begin{array}{l}\text { amanat untuk dibentuk Peraturan } \\
\text { Pemerintah sebagai Peraturan Pelaksana }\end{array}$ \\
\hline
\end{tabular}

Apabila memperhatikan 10 (sepuluh) ketentuan dalam Undang-Undang Nomor 6 tahun 2018 tersebut diatas, maka ada beberapa hal yang pada hakikatnya perlu dijelaskan dalam Peraturan Pemerintah, yaitu:

1. Terkait mitigasi faktor risiko PSBB yang kewenangannya diserahkan pada Pejabat Karantina Kesehatan, dalam penjelasan disebutkan bahwa yang dimaksud dengan Pejabat Karantina Kesehatan adalah Dokter.

Peraturan Pelaksana terkait PSBB selayaknya menjelaskan secara mendetail sejauh mana kewenangan Dokter selaku Pejabat Karantina Kesehatan dalam melakukan mitigasi faktor risiko di daerah yang telah menetapkan PSBB. Akan tetapi, dalam Peraturan Pemerintah Nomor 21 Tahun 2020, Pejabat Karantina Kesehatan bahkan tidak disebutkan satu kali pun.

2. Terkait pertimbangan di lakukannya PSBB. Menuerut UndangUndang Nomor 6 Tahun 2018, Penerapan PSBB harus dilakukan dengan sejumlah pertimbangan, yaitu:

a. Epidemiologis

b. besarnya ancaman

c. efektifitas

d. dukungan sumber daya

e. teknis operasional

f. pertimbangan ekonomi

g. sosial

h. budaya, dan 
i. keamanan

Hal-hal tersebut didalam Undang-Undang dibuat abstrak, karena memberikan kesempatan bagi Pemerintah untuk menerjemahkan pertimbangan-pertimbangan tersebut dengan sesuatu yang lebih kongkret. Sebagai gambaran sederhana, penulis akan memaparkan hal-hal yang terkait dengan pertimbangan tersebut:

1. Faktor epidemiologis dalam penanganan Covid-19 menurut panduan aman yang diterbitkan WHO adalah insidensi kasus COVID-19 konfirmasi dan kemungkinan (probable); tingkat rawat inap di rumah sakit dan UGD; jumlah kematian; proporsi hasil tes positif; hasil tes serologis. ${ }^{6}$ Namun sebagaimana yang diketahui, pertimbangan kapasitas rumah sakit maupun hal-hal tersebut tidak disinggung sama sekali dalam Peraturan Pemerintah Nomor 21 Tahun 2020.

2. Terkait besarnya ancaman sebagai upaya untuk mengantisipasi resiko yang akan muncul, keputusan untuk memberlakukan, mengadaptasi, menghentikan PSBB harus didasarkan pada penilaian resiko bermetodologi standar guna menyeimbangkan risiko pelonggaran langkah, kapasitas mendeteksi lonjakan kembali kasus, ${ }^{7}$ kapasitas mengelola jumlah pasien tambahan di fasilitas pelayanan kesehatan atau tempat-tempat lain, dan kemampuan menerapkan kembali PSBB jika diperlukan. ${ }^{8}$ Namun, hal tersebut juga tidak tercantum dalam Peraturan Pemerintah Nomor 21 Tahun 2020.

3. Efektifitas. Pada dasarnya hal itu bisa disebut efektif manakala mengurangi trend kenaikan jumlah pasien positif

6https://www.who.int/docs/default-source/searo/indonesia/covid I 9/who---pertimbanganpenyesuaian-langkah-langkah-kesehatan-masyarakat-dan-sosial-dalam-konteks-covid19.pdf?sfursn=e57I 02d4_2 diakses pada tanggal I Juni 2020

${ }^{7}$ Aneel Bhangu et al., "Global Guidance for Surgical Care during the COVID-1 9 Pandemic," British Journal of Surgery, (March 2020).

${ }^{8}$ Cavallo, J. J., Donoho, D. A., \& Forman, H. P., "Hospital capacity and operations in the coronavirus disease 2019 (COVID-19) Pandemic_-Planning for the nth patient". JAMA Health Forum, Vol. I, No.3 (2020). 
Covid-19, hipotesis tersebut sejalan dengan pendapat Looi yang menyatakan bahwa efektif dalam penanganan wabah pandemi Covid-19 berarti that the number of infections could not be brought to zero. ${ }^{9}$

4. Dukungan sumber daya, Peraturan Pemerintah sebagai peraturan pelaksana selayaknya mengatur secara mendetail terkait dukungan sumber daya baik terkait alat pelindung diri (APD) hingga bantuan tenaga medis dalam penanganan Covid-19.

5. Teknis operasional. PSBB merupakan salah satu kebijakan pemerintah yang lintas sektoral baik di internal Pemerintah Pusat ataupun antara Pemerintah Pusat dan Pemerintah Daerah. Teknis operasional sangat penting untuk diatur dalam Peraturan Pemerintah, hal itu sebagai upaya untuk memastikan tidak ada benturan kebijakan yang terjadi di lapangan. Sayangnya Peraturan Pemerintah Nomor 21 Tahun 2020 tidak mengatur sama sekali terkait teknis operasional, yang kemudian menyebabkan adanya kebijakan-kebijakan yang kontradiktif di lapangan, sebagai contoh adalah Peraturan Menteri Kesehatan Nomor 9 Tahun 2020 tentang Pedoman Pembatasan Sosial Berskala Besar dalam Rangka Percepatan Penanganan Corona Virus Disease 2019 (Covid-19) yang melarang transportasi motor untuk berboncengan selama ditetapkannya Pembatasan Sosial Berskala Besar (PSBB), akan tetapi terdapat pula Peraturan Menteri Perhubungan Nomor PM.18 Tahun 2020 tentang Pengendalian Transportasi dalam Rangka Pencegahan Penyebaran Corona Virus Disease 2019 (Covid19) yang memperbolehkan transportasi sepeda motor untuk membawa penumpang selama telah dipenuhi protokol kesehatan. Selain itu, Peraturan Pemerintah Nomor 21 Tahun 2020 juga tidak mengatur teknis penerapan PSBB, pada akhirnya tiap daerah mempunyai

9 Mun-Keat Looi, "Covid- 19: Japan Ends State of Emergency but Warns of 'New Normal'.," BMJ (Clinical Research Ed.), Vol.369 (May 2020). 
pandangan yang berbeda-beda dalam memahami PSBB. Padahal PSBB sebagai sebuah skema darurat kesehatan didasarkan pada undang-undang, oleh karena itulah aturan teknis operasionalnya selayaknya tidak berbeda antara daerah satu dengan daerah lainnya.

6. Pertimbangan ekonomi. Dalam Peraturan Pemerintah Nomor 21 Tahun 2020, tidak disebutkan sama sekali pertimbangan ekonomi dalam penerapan PSBB. Padahal penerapan PSBB berdampak besar terhadap sektor ekonomi, ${ }^{10}$ seperti pemutusan hubungan kerja (PHK) besarbesaran. ${ }^{11}$ Dikarenakan tidak adanya aturan sepesifik terkait persoalan tersebut, Kementerian-Kementerian terkait mengeluarkan kebijakan yang bervariasi, Kementerian Tenaga Kerja mengeluarkan Surat Edaran (SE) Nomor M/6/HI.00.01/V/2020 Tentang Pelaksanaan Pemberian Tunjangan Hari Raya (THR) Keagamaan Tahun 2020 di Perusahaan Dalam Masa Pandemi Corona Virus Disease 2019 (Covid-19) yang dalam pokok isinya memperbolehkan Perusahaan untuk menunda pembayaran THR. ${ }^{12}$ Selain itu Kementerian Perindustrian juga mengeluarkan Surat Edaran Menteri Perindustrian No 4 Tahun 2020 tentang Pelaksanaan Operasional Pabrik Dalam Masa Kedaruratan Kesehatan Masyarakat Corona virus Disease 2019 yang dalam pokok isinya memperbolehkan sejumlah industri tetap menjalankan aktivitasnya selama terjadi wabah pandemi, disisi lain sejumlah daerah yang menerapkan PSBB melarang adanya aktivitas tersebut. Kondisi inilah yang selayaknya diatur dalam Peraturan Pemerintah terkait PSBB.

\footnotetext{
${ }^{10}$ Kylie E C Ainslie et al., "Evidence of Initial Success for China Exiting COVID- 19 Social Distancing Policy after Achieving Containment," Wellcome Open Research, Vol. 5 (2020), 8I.

"Mildred Z. Solomon, Matthew Wynia, and Lawrence O. Gostin, "Scarcity in the Covid-19 Pandemic," The Hastings Center Report, Vol. 50, No. 2 (2020), 3.

12 https://www.cnbcindonesia.com/news/202005 I I I02 108-4-157512/surat-edaran-bikinpolemik-menaker-buka-bukaan-sanksi-thr diakses pada tanggal 2 Juni 2020
} 
f. Sosial, budaya dan keamanan. Pada hakikatnya penerapan PSBB terutama terkait pembatasan kegiatan keagamaan dalam bentuk social distancing dan physical distancing mempunyai dampak sosial serta budaya di sejumlah daerah. ${ }^{13}$ Apalagi fenomena terjadinya wabah pandemi Covid-19 bertepatan dengan dilaksanakannya ibadah puasa di bulan ramadhan, yang mana interaksi yang didasarkan aktivitas keagamaan kerap kali dilakukan seperti sholat taraweh berjamaah, ngabuburit, nyekar atau ziarah kubur, takbir keliling, sholat ied berjamaah, hingga halal bi halal. Sayangnya Peraturan Pemerintah yang selayaknya menjadi instrumen hukum untuk mengatur hal teknis tersebut justru tidak mencantumkan sama sekali terkait dampak sosial dan budaya, yang berimplikasi terhadap kebingungan yang terjadi di masyarakat.

\section{Implikasi Absurditas Regulasi}

Terdapat sejumlah poin penting dalam Undang-Undang Nomor 6 Tahun 2018 yang setidaknya harus diatur dalam Peraturan Pemerintah Nomor 21 Tahun 2020. Ketiadaan pengaturan tersebut berimplikasi terhadap kebingungan masyarakat terkait tindakan Pemerintah dalam penanganan wabah pandemi Covid-19. Salah satu hal yang selayaknya diatur dalam Peraturan Pemerintah Nomor 21 Tahun 2010 adalah terkait teknis pelaksanaan PSBB serta pembagian kewenangannya, karena pada hakikatnya dalam UndangUndang Nomor 6 tahun 2028, pelaksanaan PSBB mengatur sedikitnya tiga hal, yaitu:

1. Peliburan Sekolah dan tempat kerja

Peraturan Pemerintah selayaknya mengatur terkait dengan mekanisme peliburan sekolah, apakah peliburan yang dimaksud dalam Undang-Undang adalah sama

13 Thomas Abel and David McQueen, "The COVID- 9 Pandemic Calls for Spatial Distancing and Social Closeness: Not for Social Distancing!," International Journal of Public Health, Vol. 65, No. 3 (2020), 231. 
dengan libur sebagaimana hari nasional ataukah kemudian tetap berjalan sebagaimana mestinya namun pembelajarannya dilakukan melalui jarak jauh?. Hal tersebut selayaknya diatur dalam Peraturan Pemerintah, karena norma yang diatur dalam Undang-Undang Nomor 6 Tahun 2018 belum memberikan kejelasan. Selain itu, Peraturan Pemerintah selayaknya juga mengatur pembagian kewenangan terkait pihak yang mempunyai peranan untuk meliburkan sekolah dan tempat kerja, apakah Menteri Pendidikan dan Kebudayaan, Menteri Agama, Guburnur ataukah Bupati/Walikota.

Hal tersebut juga berlaku untuk peliburan tempat kerja, siapa yang berwenang memutuskan? Apakah Menteri Tenaga Kerja, Menteri Perindustrian, Gubernur atau Bupati/Walikota?. Ketiadaan norma hukum yang secara tegas mengatur hal tersebut menciptkan problematika dalam teknis operasionalnya, hal tersebut bisa terlihat dalam sejumlah penerapan PSBB yang kerap kali melahirkan konflik baik di internal pemerintah pusat, pemerintah pusat dengan daerah, maupun antara pemerintah provinsi dan kabupaten/kota.

2. Pembatasan aktivitas keagamaan

Salah satu kelemahan Peraturan Pemerintah Nomor 21 Tahun 2020 adalah tidak mengatur teknis pembatasan aktivitas keagamaan. Hal tersebutlah yang kemudian membuat pelaksanaan pembatasan tersebut tidak dapat berjalan dengan optimal. Hal itu disebabkan tidak jelasnya pihak yang berwenang pelakukan pembatasan, apakah Kementerian Agama, MUI, Gubernur ataukah Bupati/Walikota. Pada akhirnya kebijakan pembatasan aktivitas keagamaan terhenti sebatas pada himbauan yang sebagian besar tidak dipatuhi oleh warga negara. Disisi lain, Pemerintah daerah juga tidak mampu untuk melakukan penindakan karena tidak adanya dasar hukum yang melarang hal tersebut secara tegas. 
3. Pembatasan kegiatan di tempat atau fasilitas umum.

Hal serupa juga terjadi terkait pembatasan kegiatan di tempat atau fasilitas umum, dimana Peraturan Pemerintah Nomor 21 Tahun 2020 tidak menjelaskan secara mendetail tempat atau fasilitas umum seperti apakah yang dibatasi?. Ketiadaan kriteria membuat pelaksanaan pembatasan tidak berjalan optimal. Selain itu tidak ada penjelasan aturan teknisnya siapa yang bertanggung jawab serta manakala terjadi pelanggaran, apakah akan mendapatkan sanksi ataukah tidak?.

Berdasarkan hal-hal tersebut diatas, menurut penulis Peraturan Pemerintah Nomor 21 Tahun 2020 tentang Pembatasan Sosial Berskala Besar Dalam Rangka Percepatan Penanganan Corona Virus Disease 2019 (Covid-19) belum menjelaskan secara teknis pelaksanaan Pembatasan Sosial Berskala Besar (PSBB) sebagaimana yang tercantum dalam Undang-Undang Nomor 6 Tahun 2018 tentang Kekarantinaan Kesehatan, karena setidknya terdapat sejumlah hal yang selayaknya harus tercantum dalam peraturan pemerintah tersebut, yaitu:

Tabel 4

Hal-Hal yang Seharusnya diatur di Peraturan Pemerintah Nomor 21 Tahun 2020

\begin{tabular}{|l|l|}
\hline Perihal & Keterangan \\
\hline Pertimbangan Epidemiologis & Tidak ada \\
\hline Kriteria besarnya ancaman & Tidak ada \\
\hline Indikator efektifitas & Tidak ada \\
\hline Pemenuhan dukungan sumber daya & Tidak ada \\
\hline Teknis operasional PSBB & Tidak ada \\
\hline Pertimbangan ekonomi dampak PSBB & Tidak ada \\
\hline $\begin{array}{l}\text { Pertimbangan sosial, budaya, dan } \\
\text { keamanan }\end{array}$ & Tidak ada \\
\hline Teknis Peliburan Sekolah & Tidak ada \\
\hline
\end{tabular}


Problematika Yuridis Peraturan

\begin{tabular}{|l|l|}
\hline Teknis Peliburan Tempat Kerja & Tidak ada \\
\hline $\begin{array}{l}\text { Mekanisme Pembatasan Aktivitas } \\
\text { Keagamaan }\end{array}$ & Tidak ada \\
\hline $\begin{array}{l}\text { Kriteria Pembatasan Kegiatan di } \\
\text { Fasilitas Umum }\end{array}$ & Tidak ada \\
\hline Pejabat Karantina Kesehatan kewenangan antar & Tidak ada \\
\hline $\begin{array}{l}\text { Pembagian ada } \\
\text { Kementerian }\end{array}$ & Tidak ada \\
\hline $\begin{array}{l}\text { Pembagian kewenangan Provinsi dan } \\
\text { Kabupaten/Kota }\end{array}$ & Tidak ada \\
\hline
\end{tabular}

Terlihat berdasarkan tabel diatas, ketiadaan hal-hal tersebutlah yang membuat Peraturan Pemerintah dapat dikategorikan sebagai hukum yang cacat (flawed law) yang menurut Radbruch terjadi ketika substansi hukum gagal menghadirkan keadilan serta manfaat bagi setiap orang. ${ }^{14}$

\section{Penutup}

Peraturan Pemerintah Nomor 21 Tahun 2020 tentang Pembatasan Sosial Berskala Besar Dalam Rangka Percepatan Penanganan Corona Virus Disease 2019 (Covid-19) apabila dilihat dalam kajian ilmu perundang-undangan dapat dikategorikan sebagai peraturan yang cacat (flawed law), hal itu dilihat beradasarkan pembentukannya (formil) yang tidak mempertimbangkan aspek antisipatif (futuristis), daya tahun (durability) dan umur yang panjang (longevity). Selain itu dilihat dari aspek materiilnya, Peraturan Pemerintah Nomor 21 Tahun 2020 juga menyimpan sejumlah persoalan. Hal itu disebabkan sebagai peraturan pelaksana dari Undang-Undang Nomor 6 Tahun 2018, Peraturan Pemerintah Nomor 21 Tahun 2018 justru tidak menjelaskan aturan-aturan teknis yang tercantum dalam Undang-Undang. Hal tersebut kemudian berimplikasi terhadap pelaksanaan Pembatasan Sosial

${ }^{14}$ Peter Langford, lan Bryan, and John McGarry, Hans Kelsen and the Natural Law Tradition (Boston: Brill, 2019), 507. 
Berskala Besar (PSBB) yang tidak optimal, seperti tidak adanya koordinasi lintas kementerian, hingga benturan regulasi antara Pemerintah Provinsi dan Kabupaten/Kota.

Berdasarkan hal-hal tersebut diatas, Penulis menyarankan Pemerintah untuk membuat Peraturan Pemerintah baru yang membahas penerapan PSBB secara umum serta harus menjelaskan secara mendetail terkait pembagian kewenangan antara kementerian satu dengan kementerian yang lain, serta pemerintah daerah baik di tingkat provinsi maupun kabupaten/kota.

\section{Daftar Pustaka}

Abel, Thomas, and David McQueen. "The COVID-19 Pandemic Calls for Spatial Distancing and Social Closeness: Not for Social Distancing!" International Journal of Public Health 65, no. 3 (2020): 231. https://doi.org/10.1007/s00038-020-01366-7.

Ainslie, Kylie E C, Caroline E. Walters, Han Fu, Sangeeta Bhatia, Haowei Wang, Xiaoyue Xi, Marc Baguelin, et al. "Evidence of Initial Success for China Exiting COVID-19 Social Distancing Policy after Achieving Containment." Wellcome Open Research 5 (2020): 81. https://doi.org/10.12688/wellcomeopenres.15843.1.

Arnold, Craig, and Lance Gunderson. "Adaptive Law and Resilience." Environmental Law Reporter, no. 5 (2013): 10426-43.

http://papers.ssrn.com/sol3/papers.cfm?abstract_id=2225 619.

Asshiddiqie, Jimy. Perihal Undang-Undang. Jakarta: Konstitusi Press, 2006.

Bhangu, Aneel, Ismail Lawani, Joshua S. Ng-Kamstra, Yanfeng Wang, Albert Chan, Kaori Futaba, Simon $\mathrm{Ng}$, et al. "Global Guidance for Surgical Care during the COVID-19 Pandemic." British Journal of Surgery, no. March (2020). https://doi.org/10.1002/bjs.11646. 
Fauzan, H.M. Kaidah Penemuan Hukum Yurisprudensi Bidang Hukum Perdata. Jakarta: Prenada Media, 2014.

Houssein, Zainal Arifin. "Pembentukan Hukum Dalam Perspektif Pembaruan Hukum." Rechtsvinding 1, no. 3 (2012): 257-75.

Indrarti, Maria Farida. Ilmu Perundang-Undangan. Jakarta: Kanisius, 2007.

- - - Ilmu Perundang-Undangan. Yogyakarta: Kanisius, 1998. Langford, Peter, Ian Bryan, and John McGarry. Hans Kelsen and the Natural Law Tradition. Boston: Brill, 2019.

Looi, Mun-Keat. "Covid-19: Japan Ends State of Emergency but Warns of 'New Normal'." BMJ (Clinical Research Ed.) 369, no. May (2020): m2100. https://doi.org/10.1136/bmj.m2100.

Maftuh, Effendi, and Tri Cahya Indera Permana. "Usulan Rumusan Hukum Acara (Ius Constituendum ) Pengujian Peraturan Perundang-Undangan Di Bawah UndangUndang Oleh Mahkamah Agung." Media Hukum 2, no. 1 (2018): 31-39.

Rimmer, Abi. “Covid-19: Doctors Still Do Not Have \#properPPE." BMJ (Clinical Research Ed.) 369, no. April (2020): m1423. https://doi.org/10.1136/bmj.m1423.

Solomon, Mildred Z., Matthew Wynia, and Lawrence O. Gostin. "Scarcity in the Covid-19 Pandemic." The Hastings Center Report 50, no. 2 (2020): 3. https://doi.org/10.1002/hast.1093.

Sukardi, Sukardi, and E. Prajwalita Widiati. "Pendelegasian Pengaturan Oleh Undang-Undang Kepada Peraturan Yang Lebih Rendah Dan Akibat Hukumnya." Yuridika 27, no. 2 (2012): 103-16. https://doi.org/10.20473/ydk.v27i2.293.

Thohari, Ahmad Ahsin. "Pendek Umur Peraturan." Kompas, July 15, 2015. 